\title{
Demographic decline of the last surviving Moroccan dorcas gazelles Gazella dorcas massaesyla in M'Sabih Talaa Reserve, Morocco
}

\author{
Moulay A bieljalil Ait Baamrane, Mohammed Znari, Chris Loggers \\ Said El MerCht and Mohamed Naimi
}

\begin{abstract}
The formerly widespread but now Vulnerable dorcas gazelle Gazella dorcas has declined markedly during the last 2 decades. The semi-captive population in M'Sabih Talaa Reserve, west-central Morocco, is genetically distinct and may be the last remnant of the Moroccan dorcas gazelle $G$. dorcas massaesyla. The last estimate of the size of this population was c. 200, in 1996. To assess the current population we used line-transect distance sampling to survey this population over five seasons from April 2008 to August 2009. The estimated population declined from 113 to 87 individuals from April to November 2008, increased to 111 in February 2009 (primarily because of recruitment), declined to 99 from February to April 2009, and to 95 by August 2009. These results indicate a decline of nearly $50 \%$ in $<15$ years. The main conservation actions required for this subspecies are the suppression of poaching and feral dogs, the creation of other reserves to receive dorcas gazelles from M'Sabih Talaa (to avoid loss of the single population from a catastrophic event), and the implementation of a genetic management programme.
\end{abstract}

Keywords Antelope, distance sampling, Moroccan dorcas gazelle, Gazella dorcas massaesyla, line transects, Morocco, population estimate

\section{Introduction}

K nowledge of population demography is essential for understanding the ecology of a species, providing information on fluctuations of population size, and facilitating monitoring of trends. For threatened species population estimates are vital for the development of conservation strategies and for evaluating their effectiveness

Moulay AbDEljalil Ait BaAmRane (Corresponding author), MOHAMmEd ZnARI and Mohamed Naimi Laboratory Biodiversity and Ecosystem Dynamics, Department of Biology, Faculty of Science-Semlalia, Cadi Ayyad University, Avenue Prince Moulay Abdellah, P.O. Box 2390, 40000 Marrakech, Morocco. E-mail aitbaamrane.m.a@gmail.com

Chris Loggers United States Forest Service, Colville National Forest, Kettle Falls, Washington, USA

SAID El MERChT Regional Center of Forestry Research, Marrakech, Morocco

Received 12 January 2012. Revision requested 13 March 2012.

Accepted 26 March 2012. First published online 8 August 2013. but obtaining population estimates for species that occur at low densities over a large geographical area is logistically difficult.

The dorcas gazelle Gazella dorcas is categorized as Vulnerable on the IUCN Red List (IUCN SSC Antelope Specialist Group, 2008) and is considered Endangered in Morocco (Cuzin, 1996, 2003; Aulagnier et al., 2001). The species has declined precipitously throughout Morocco because of poaching and severe habitat degradation from the expansion of agriculture and increased livestock grazing pressure. Dorcas gazelles have been fully protected since 1958, when the Moroccan ministerial order that regulates hunting prohibited their shooting. In Morocco this gazelle species historically occupied the plains north of the Atlas mountains (Panouse, 1957; Alados, 1987) but now persists only as a remnant population, isolated within a 1,987-ha reserve established in 1952 at M'Sabih Talaa in west-central Morocco. Recent genetic analyses (Godinho et al., 2012), including data from Lerp et al. (2011), indicate that the population in M'Sabih Talaa Reserve is genetically differentiated, both in terms of mtDNA and nuclear DNA, and may be the last surviving population of $G$. dorcas massaesyla, isolated from G. dorcas dorcas and G. dorcas neglecta by the High and Middle Atlas mountains (Alados, 1987).

The size of the dorcas gazelle population in M'Sabih Talaa Reserve has fluctuated considerably. In 1987 Loggers (1992), using data from a 2-year study, estimated the population size to be c. 210 in the wet season and 190 in the dry season. Cuzin (1996, in Mallon \& Kingswood, 2001) reported the population to be 80 but based this on estimates from the Reserve guards rather than on his own observations. This information appears to be inaccurate, although during droughts the population probably declines because of increased mortality and emigration (Loggers, 1992). In 1996, using the line-transect distance sampling method, Marraha (1996) estimated the mean population size to be 184. However, none of these various estimates contained confidence intervals and the population has not been monitored since 1996.

Here we report a recent survey of the dorcas gazelle in the M'Sabih Talaa Reserve. From spring 2008 to summer 2009 we used the line-transect distance sampling method (Buckland et al., 2004) to estimate density, and hence 


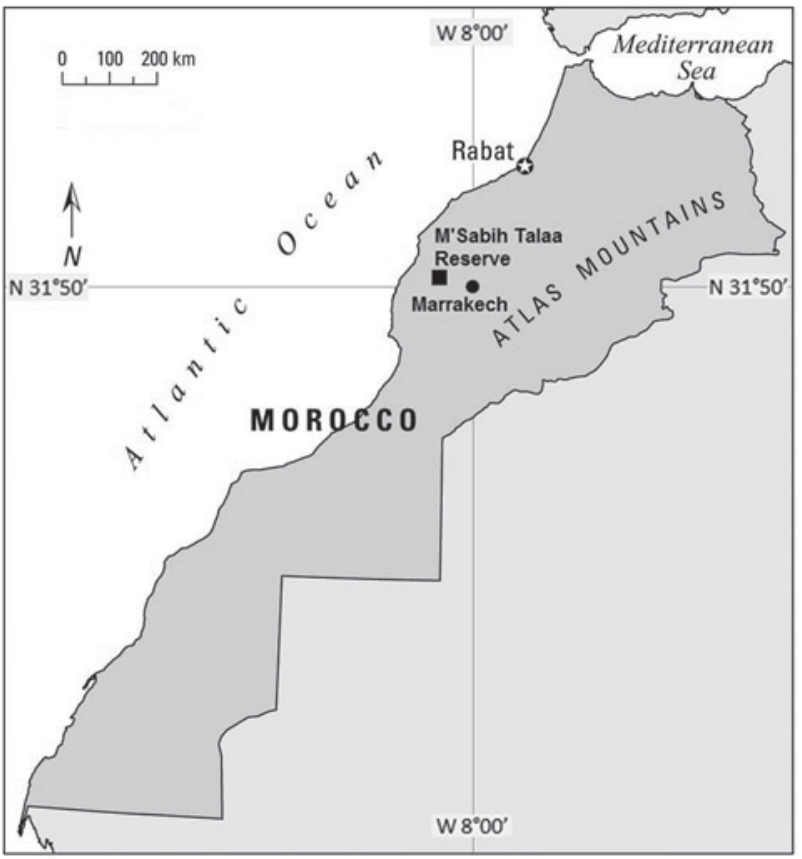

FIG. 1 Morocco, showing the location of M'Sabih Talaa Reserve (the black square) on the Ahmar Plain to the west of the Atlas Mountains.

population size, and seasonal variations, and document demographic structure. The results obtained were compared to earlier estimates of the same population.

\section{Study area}

The 1,987-ha M'Sabih Talaa Reserve lies on the Ahmar Plain near Sidi Chiker Village in Safi Province, $65 \mathrm{~km}$ west of Marrakech (Fig. 1). The climate is arid, with a mean annual precipitation of $238 \pm 88.3 \mathrm{~mm}$ falling mainly between November and March. The mean annual temperature is $20^{\circ} \mathrm{C}$, with a monthly mean minimum and maximum of $5^{\circ} \mathrm{C}$ in January and $40^{\circ} \mathrm{C}$ in July, respectively. The Reserve consists of small ravines among gently rolling hills covered by a jujube Ziziphus lotus shrub-steppe, with Stipa cappensis as the dominant grass (Loggers, 1991, 1992). Along wadis (intermittent streams) that cut through the Reserve Eucalyptus trees have been sparsely planted. The Reserve is entirely fenced, and hence the dorcas gazelle is semi-captive, but the fence is too low and is damaged in many places, facilitating access by feral dogs and poachers.

\section{Methods}

Distance sampling has been used extensively to survey wild ungulates, by observing animals or their signs, in various habitats (Marques et al., 2001; Biswas \& Sankar, 2002; Koenen et al., 2002; Seddon et al., 2003; Whittaker et al., 2003; Focardi et al., 2005). The line-transect method (Buckland et al., 1993) was used to survey the dorcas gazelle population in the M'Sabih Talaa Reserve as it is one of the most frequently used and widely accepted methods for estimating the density of wild animals (Seber, 1986; Schwarz \& Seber, 1999). The method requires that animals are counted while an observer moves along a transect line, and the density estimate is based on the detection probability estimated from the linear distances between detected animals and the observer (Buckland et al., 1993).

Fourteen line transects, with a total length of $42.3 \mathrm{~km}$, were defined randomly using a global positioning system, to ensure that the entire Reserve was covered systematically. The study was conducted over five successive seasons (spring and autumn, 2008 and winter, spring and summer, 2009), with four surveys per season. Surveys were conducted to coincide with the daily activity of gazelles (05.30-09.30 and 16.00-19.30). Transects were not repeated on the same or consecutive days. The observer walked at an average of $5 \mathrm{~km} \mathrm{~h}^{-1}$, traversing each transect alternately once or twice per week. For each individual or group detected, the observer measured the distance to the subject with a laser rangefinder and measured the angle to the transect. The data were analysed using Distance v. 5.o (Thomas et al., 2010), which models the function of the detection, describing the decrease in the probability of detecting the subject according to the perpendicular distance from the centre of the transect line.

The total population size was estimated by extrapolating the mean density to the total area of the Reserve. The population structure was determined using age classes based on body size and horn structure (Loggers, 1992). The classes considered were fawns (0-12 months), subadults (12-18 months for males, 12-24 months for females), and adults (up to 18 months for males, up to 24 months for females). Observations were made using a $20-60 \times$ telescope. The groups of animals encountered along transect lines were assumed to be representative of the population's demographic structure.

We tested 12 models (Thomas et al., 2005, 2010) using Distance. The selection of the adequate model (Buckland et al., 1993, 2004) was based on the shape of the curve describing the probability of detecting gazelles in relation to the recorded perpendicular distances, the AIC (Akaike information criterion) value, and the value of a $\chi^{2}$ goodnessof-fit test. The best models have a curve showing a reduction in the probability of detection with increase in distance between the observer and the animal, and the lowest AIC value.

As we wished to detect any seasonal variations we computed density separately for each season. Seasonal comparisons of density estimates were made with paired sample $t$-tests. All statistical tests were carried out using SPSS v. 10 (SPSS, Chicago USA). ANOVAs were used to test for significant seasonal changes, and paired Student $t$-tests to examine differences between means. Differences were considered statistically significant at $\mathrm{P}<0.05$. 
TABLE 1 Analysis of the results of the line-transect surveys of the Moroccan dorcas gazelle Gazella dorcas massaesyla in M'Sabih Talaa Reserve, Morocco (Fig. 1), in five seasons from spring 2008 to summer 2009 (there were four surveys in each season), with the selected models (key/adjustment) and their AIC (Akaike information criterion) value, probability of the $\chi^{2}$ goodness-of-fit test, effective strip width (ESW), mean estimated density and its coefficient of variation (CV), and the estimated population size for each line transect survey session and for the season overall.

\begin{tabular}{|c|c|c|c|c|c|c|c|}
\hline Survey (by season) & Model $^{*}$ & AIC & $\chi^{2} \mathrm{P}$ & ESW (m) & Density $\left(\mathrm{ha}^{-1}\right)$ & $\mathrm{CV}$ of density & Population size \\
\hline \multicolumn{8}{|l|}{ Spring 2008} \\
\hline 1 & $\mathrm{HR} / \mathrm{C}$ & 214.5 & 0.34 & 284.28 & 0.062 & 19.2 & 123 \\
\hline 2 & $\mathrm{HR} / \mathrm{C}$ & 115.2 & 0.55 & 215.22 & 0.05 & 20.8 & 99 \\
\hline 3 & $\mathrm{HN} / \mathrm{HP}$ & 126.8 & 0.72 & 248.68 & 0.061 & 22.2 & 121 \\
\hline 4 & $\mathrm{HR} / \mathrm{C}$ & 103.7 & 0.39 & 217.85 & 0.055 & 18.5 & 109 \\
\hline Mean $\pm S D$ & & & & $291.49 \pm 73.97$ & $0.057 \pm 0.006$ & $20.18 \pm 1.66$ & $113 \pm 11$ \\
\hline \multicolumn{8}{|l|}{ Autumn 2008} \\
\hline 1 & $\mathrm{U} / \mathrm{C}$ & 354.6 & 0.63 & 178.55 & 0.041 & 24.5 & 81 \\
\hline 2 & $\mathrm{U} / \mathrm{SP}$ & 336.5 & 0.47 & 302.44 & 0.037 & 19.4 & 74 \\
\hline 3 & $\mathrm{U} / \mathrm{C}$ & 316.5 & 0.52 & 174.40 & 0.056 & 21.9 & 111 \\
\hline 4 & $\mathrm{U} / \mathrm{HP}$ & 246.9 & 0.44 & 250.07 & 0.041 & 19.9 & 81 \\
\hline Mean $\pm S D$ & & & & $226.37 \pm 61.47$ & $0.044 \pm 0.009$ & $21.43 \pm 2.32$ & $87 \pm 18$ \\
\hline \multicolumn{8}{|l|}{ Winter 2009} \\
\hline 1 & $\mathrm{U} / \mathrm{C}$ & 332.3 & 0.34 & 149.24 & 0.052 & 24.7 & 103 \\
\hline 2 & $\mathrm{U} / \mathrm{C}$ & 294.5 & 0.55 & 145.39 & 0.057 & 22.4 & 113 \\
\hline 3 & U/SP & 341.9 & 0.72 & 272.66 & 0.053 & 24.1 & 105 \\
\hline 4 & $\mathrm{U} / \mathrm{C}$ & 308.4 & 0.39 & 152.72 & 0.061 & 22.2 & 121 \\
\hline Mean $\pm S D$ & & & & $180.00 \pm 61.84$ & $0.056 \pm 0.004$ & $23.35 \pm 1.24$ & $111 \pm 8$ \\
\hline \multicolumn{8}{|l|}{ Spring 2009} \\
\hline 1 & $\mathrm{U} / \mathrm{C}$ & 419.9 & 0.74 & 127.00 & 0.053 & 23.5 & 105 \\
\hline 2 & $\mathrm{U} / \mathrm{C}$ & 284.3 & 0.75 & 141.64 & 0.046 & 23.1 & 91 \\
\hline 3 & $\mathrm{U} / \mathrm{HP}$ & 340.6 & 0.22 & 187.31 & 0.048 & 17.6 & 95 \\
\hline 4 & U/HP & 399.9 & 0.69 & 203.52 & 0.053 & 19.1 & 105 \\
\hline$M e a n \pm S D$ & & & & $164.87 \pm 36.38$ & $0.050 \pm 0.004$ & $20.83 \pm 2.93$ & $99 \pm 8$ \\
\hline \multicolumn{8}{|l|}{ Summer 2009} \\
\hline 1 & $\mathrm{U} / \mathrm{HP}$ & 345.2 & 0.44 & 139.53 & 0.051 & 20.3 & 101 \\
\hline 2 & $\mathrm{U} / \mathrm{C}$ & 297.3 & 0.75 & 158.90 & 0.042 & 17.9 & 83 \\
\hline 3 & $\mathrm{U} / \mathrm{SP}$ & 314.5 & 0.25 & 213.06 & 0.044 & 21.5 & 87 \\
\hline 4 & $\mathrm{U} / \mathrm{SP}$ & 401.2 & 0.32 & 264.25 & 0.055 & 24.2 & 109 \\
\hline$M e a n \pm S D$ & & & & $193.94 \pm 56.27$ & $0.048 \pm 0.006$ & $20.98 \pm 2.62$ & $95 \pm 12$ \\
\hline
\end{tabular}

${ }^{*} \mathrm{U}$, uniform; HR, hazard rate; HN, half normal; C, cosine; SP, simple polynomial; HP, Hermite polynomial (Buckland et al., 2004)

\section{Results}

The vegetation of the Reserve is sparse and consequently visibility is good, and the transect lines enabled us to obtain a large sample size and cover a large proportion of the area. The sampling efficiency is indicated by the percentage cover of the study area, which depends on the effective strip width. This varied among observation series (127-302 m; Table 1). The areas sampled along transects, calculated from the effective strip width and transect length, were $6.97-9.58 \mathrm{~km}^{2}$ (i.e. $35-48 \%$ of the total area of the Reserve).

The mean density estimates (Table 1) varied significantly among seasons (one-way ANOVA: $F_{1,4}=3.607, \mathrm{P}<0.05$ ). The estimated population declined significantly from 113 to 87 individuals between April and November $2008(t=4.045$, $\mathrm{df}=3, \mathrm{P}<0.05)$, and then increased non-significantly to $111(t=-2.209, \mathrm{df}=3, \mathrm{P}=0.114)$ in February 2009, primarily because of recruitment. After a non-significant decline to $99(t=2.649 ; \mathrm{df}=3 ; \mathrm{P}=0.077)$ from February to April 2009, the estimated population remained nearly constant, at 95, in August 2009.

A total of 1,835 animals were detected over all surveys (Table 2), of which $54 \%$ were adults ( $21.4 \%$ males, $32.6 \%$ females), $40.1 \%$ were subadults ( $14.1 \%$ males, $26 \%$ females) and $5.9 \%$ were fawns. Irrespective of age, and excluding fawns, 36.1 and $63.9 \%$ of individuals were male and female, respectively. One-way ANOVAs indicated no significant seasonal changes in demographic structure (proportions of males/females, and of age classes, excluding fawns). The female:male ratio averaged $1.64 \pm$ SD 0.07 (range 1.53-1.73). Estimates of fecundity were based on results from the transect surveys (i.e. fawns accompanying their mothers) and do not account for post-partum mortality. 
TABle 2 Demography (numbers and percentages) of the Moroccan dorcas gazelle in the M' Sabih Talaa Reserve, Morocco (Fig. 1), surveyed over five seasons in 2008-2009.

\begin{tabular}{|c|c|c|c|c|c|c|c|c|c|c|}
\hline & \multicolumn{2}{|c|}{ Spring 2008} & \multicolumn{2}{|c|}{ Autumn 2008} & \multicolumn{2}{|c|}{ Winter 2009} & \multicolumn{2}{|c|}{ Spring 2009} & \multicolumn{2}{|c|}{ Summer 2009} \\
\hline & $\mathrm{n}$ & $\%$ & $\mathrm{n}$ & $\%$ & $\mathrm{n}$ & $\%$ & $\mathrm{n}$ & $\%$ & $\mathrm{n}$ & $\%$ \\
\hline Males & 184 & 39.48 & 127 & 36.59 & 165 & 38.01 & 103 & 37.73 & 95 & 37.25 \\
\hline Females & 282 & 60.52 & 220 & 63.41 & 269 & 61.99 & 170 & 62.27 & 160 & 62.75 \\
\hline Adult males & 105 & 21.04 & 78 & 22.51 & 103 & 20.45 & 62 & 21.18 & 57 & 21.69 \\
\hline Adult females & 166 & 33.27 & 115 & 33.21 & 156 & 31.09 & 89 & 31.17 & 89 & 34.21 \\
\hline Subadult males & 79 & 15.83 & 49 & 14.01 & 62 & 12.44 & 41 & 13.89 & 38 & 14.53 \\
\hline Subadult females & 116 & 23.25 & 105 & 30.27 & 113 & 22.51 & 78 & 26.52 & 71 & 27.23 \\
\hline Fawns & 33 & 6.61 & 0 & & 21 & 13.51 & 7 & 7.24 & 2 & 2.34 \\
\hline
\end{tabular}

The maximum apparent fecundity rate, recorded in winter (February) 2009, was $0.44 \pm \mathrm{SD} 0.02$ fawns per adult female.

\section{Discussion}

The mean population estimates of 111 and 99 dorcas gazelles in winter and spring 2009, respectively, in M'Sabih Talaa Reserve are 42.8 and 52.6\% lower than Marraha's (1996) corresponding estimates of 194 and 209, the only other available estimates. The corresponding density estimates of 0.056 individuals per ha in winter 2009 and 0.050 in spring 2009 are also lower than those estimated by Marraha (1996; 0.105 in winter 1996 and 0.092 in spring 1995) and by Loggers (1992; 0.096 in late summer-autumn 1986 and 0.104 in winter 1987), suggesting a population decline during the previous 14 years. Present and past density estimates in M'Sabih Talaa are lower than the density of dorcas gazelles in the Ténéré Nature Reserve (Niger), a sandy hyperarid (annual rainfall range $0-75 \mathrm{~mm}$ ) region in the south central Sahara, where the density reached $0.16 \mathrm{ha}^{-1}$ (Grettenberger, 1987), but higher than the density of the species in Makhtesh Ramon (mean annual rainfall $56 \mathrm{~mm}$ ) in the Negev desert (0.002-0.020 ha ${ }^{-1}$; Lawes \& Nanni, 1993). Both of these areas are sparsely vegetated, with most vegetation concentrated along watercourses.

We reviewed other estimates of the population of the dorcas gazelle in M'Sabih Talaa Reserve. Cuzin et al. (2007) reported an estimated 600-700 individuals in October 2006 based on accounts given by Reserve rangers. However, population estimates based on non-systematic methods should not be considered when making comparisons, as such estimates can establish incorrect assumptions (Caughley, 1974) that can drive misguided management strategies. The periodic fluctuation of the population size and age structure of the dorcas gazelle in the Reserve may indicate that recruitment of young cannot compensate for mortality. Causes and levels of mortality in this population need to be examined and monitored.

The observed population structure of the dorcas gazelle in M'Sabih Talaa Reserve is similar to that of other territorial, polygynous ungulates. The sex ratio is biased in favour of females, as reported for other populations of the same species (Grettenberger, 1987; Lawes \& Nanni, 1993). The mean sex ratio observed in our study was higher than that reported for the same population in September 1986 (1.30; Loggers, 1992) but slightly lower than reported in April 1995 (1.85; Marraha, 1996). The highest value recorded for the species is 3.00 , for the Hai-Bar dorcas gazelle population in the Negev desert (Baharav, 1980).

As the breeding period of the dorcas gazelle in the arid environment of Israel is from September to November (Yom-Tov et al., 1995) and given a gestation period of c. 6 months recorded in captive individuals (Slaughter, 1971), the maximum number of fawns would be expected to occur from winter to early spring. The maximum apparent fertility rate (the number of fawns per adult female) recorded in the M'Sabih Talaa Reserve population, in February 2009, was lower than those recorded for the same population in January 1995 (0.77; Marraha, 1996), September 1986 (0.91) and January-February 1987 (o.83; Loggers, 1992). These values are within the range of $0-2.18$ recorded in captive 1-8 year old female dorcas gazelles in the Estacion Experimental de Zonas Aridas, Spain (Alados \& Escos, 1991).

In all seasons adults constituted the largest percentage of the total population (51-59\%), followed by immatures (35-41\%). Marraha (1996), using the same methods, recorded similar percentages of adults $(58-61 \%)$ but lower percentages of immatures (14.7\% in April 1995, and 31.4\% in January 1996). The decline of fawns from $13.5 \%$ of the population in February 2009 to 2.34\% in August 2009, with no significant increase in immature individuals (41-39\%), may indicate either a decrease in fertility rate or an increase in fawn and immature mortality rates during spring and summer. This could have been caused by feral dogs and/or poachers (Baba Khouya, pers. comm.). We suggest that the combined effects of the apparently lower fertility rate and higher mortality rate may explain the apparent decline of the dorcas gazelle population in the M'Sabih Talaa Reserve.

The population of dorcas gazelles in M'Sabih Talaa Reserve is the remnant of the Moroccan dorcas gazelle population formerly widespread on the interior plains north 
of the Atlas mountains. The nearest groups of wild dorcas gazelles are in the Souss Valley, south of the western High Atlas mountains, where the last record of dorcas gazelles was in 1987 (Cuzin, 2003). In eastern Morocco, on the other side of the Atlas range, the species currently occurs only within the fenced reserve of El Kheng (Cuzin, 2003). The M'Sabih Talaa population has therefore probably been isolated for c. 60 years, which could have led to inbreeding depression. This is yet to be examined genetically, however. Long-term monitoring is needed to obtain more information on population dynamics, particularly mortality and fecundity rates. Such data, along with information on population genetics, are required for a population viability analysis. Such an analysis would provide the appropriate authorities with a robust scientific base from which to establish a conservation strategy for the remnant and isolated population in the M'Sabih Talaa Reserve.

Because of a lack of technical staff and rangers the population of the M'Sabih Talaa Reserve continues to decline and may soon fall below the minimal viable population size unless action is taken. The last estimate of the population size, in autumn 2010, was $<80$ individuals (authors, unpubl. data). We recommend that strict conservation measures are implemented to preserve this threatened subspecies of the dorcas gazelle. The main conservation actions required are the suppression of poaching and feral dogs, the creation of other reserves to receive dorcas gazelles from M'Sabih Talaa (to avoid loss of the single population from a catastrophic event), and the implementation of a genetic management programme. Reinforcement programmes also need to be avoided, as suggested by Mallon \& Kingswood (2001), as these would compromise this unique population by the admixture of individuals of different origins.

\section{Acknowledgements}

We wish to thank Z. Baba Khouya and the personnel of the M'Sabih Talaa Reserve for providing accommodation and assistance during the fieldwork. This study was supported by a grant to M. Znari from People's Trust for Endangered Species, London, UK. We also thank the Haut Commissariat aux Eaux et Forêts et à la Lutte Contre la Désertification (Morocco) for their support and permits. We are grateful to the anonymous reviewers for improvement of the style and structure of the manuscript.

\section{References}

Alados, C.L. (1987) A cladistic approach to the taxonomy of the dorcas gazelle. Israel Journal of Zoology, 34, 33-49.

Alados, C.L. \& Escos, J. (1991) Alarm calls and flight behaviour in Spanish ibex (Capra pyrenaica). Biology of Behaviour, 13, 11-21.
Aulagnier, S., Cuzin, F., Loggers, C. \& Thevenot, M. (2001) Morocco. In Global Survey and Regional Action Plan, Antelopes, Part 4: North Africa, the Middle East, and Asia (eds D.P. Mallon \& S.C. Kingswood), pp. 272. IUCN, Gland, Switzerland.

BAHARAV, D. (1980) Habitat utilization of the dorcas gazelle in a desert saline area. Journal of Arid Environments, 3, 161-167.

Biswas, S. \& SANKar, K. (2002) Prey abundance and food habit of tigers (Panthera tigris tigris) in Pench National Park, Madhya Pradesh, India. Journal of Zoology, 256, 411-420.

Buckland, S.T., Anderson, D.R., Burnham, K.P. \& Laake, J.L. (1993) Distance Sampling: Estimating Abundance of Biological Populations. Chapman and Hall, London, UK.

Buckland, S.T., Anderson, D.R., Burnham, K.P., Laake, J.L., Borchers, D.L. \& Thomas, L. (2004) Advanced Distance Sampling: Estimating Abundance of Biological Populations. Oxford University Press, Oxford, UK

Caughley, G. (1974) Bias in aerial survey. Journal of Wildlife Management, 38, 921-933.

Cuzin, F. (1996) Réparation actuelle et statut des grands mammifères sauvages du Maroc (Primates, Carnivores, Artiodactyles). Mammalia, 60, 101-124.

Cuzin, F. (2003) Les grands Mammifères du Maroc méridional (Haut Atlas, Anti Atlas, Sahara). Distribution, écologie et conservation. PhD thesis. EPHE, Montpellier II, Montpellier, France.

Cuzin, F., Sehhar, E.A. \& Watcher, T. (2007) Etude pour l'élaboration de lignes directrices et d'un plan d'action stratégique pour la conservation des ongulés au Maroc. Haut Commissariat aux Eaux et Forêts et à la Lutte contre la Désertification, Projet de Gestion des Aires Protégées et Banque Mondiale, Global Environment Facility, Rabat, Morocco.

Focardi, S., Montanaro, P., Isotti, R., Ronchi, F., Scacco, M. \& Calmanti, R. (2005) Distance sampling effectively monitored a declining population of Italian roe deer Capreolus capreolus italicus. Oryx, 39, 421-428.

Godinho, R., Abáigar, T., Lopes, S., Essalhi, A., Ouragh, L., Cano, M. \& Ferrand, N. (2012) Conservation genetics of the endangered dorcas gazelle (Gazella dorcas spp.) in northwestern Africa. Conservation Genetics, 13, 1003-1015.

Grettenberger, J. (1987) Ecology of the dorcas gazelle in northern Niger. Mammalia, 51, 527-536.

IUCN SSC (Species Survival Commission) Antelope Specialist Group (2008) Gazella dorcas. In IUCN Red List of Threatened Species v. 2012.2. Http://www.iucnredlist.org [accessed 17 May 2013].

Koenen, K.G., Destefano, S. \& Krausman, P.R. (2002) Using distance sampling to estimate seasonal densities of desert mule deer in a semi-desert grassland. Wildlife Society Bulletin, 30, 53-63.

Lawes, M.J. \& Nanni, R.F. (1993) The density, habitat use and social organization of dorcas gazelles (Gazella dorcas) in Makhtesh Ramon, Nagev Desert, Israel. Journal of Arid Environments, 24, 177-196.

Lerp, H., Wronski, T., Pfenninger, M. \& Plath, M. (2011) A phylogeographic framework for the conservation of Saharan and Arabian dorcas gazelles (Artiodactyla: Bovidae). Organisms Diversity and Evolution, 11, 317-329.

LOGGERS, C.O. (1991) Forage availability versus seasonal diets, as determined by fecal analysis, of dorcas gazelles in Morocco. Mammalia, 55, 255-268.

Loggers, C.O. (1992) Population characteristics of dorcas gazelles in Morocco. African Journal of Ecology, 30, 301-308.

Mallon, D.P. \& Kingswood, S.C. (2001) Antelopes. Part 4: North Africa, the Middle East and Asia. Global Survey and Regional Action Plans. Species Survival Commission Antelope Specialist Group. IUCN, Gland, Switzerland, and Cambridge, UK. 
Marques, F.F.C., Buckland, S.T., Goffin, D., Dixon, C.E. Borchers, D.L., Mayle, B.A. \& Peace, A.J. (2001) Estimating deer abundance from line transect surveys of dung: sika deer in southern Scotland. Journal of Applied Ecology, 38, 349-363.

Marraha, M. (1996) Utilisation du line transect dans l'estimation de la densité et des caractéristiques de la population de gazelle dorcas (Gazella dorcas L.) dans la réserve de M'Sabih Talaa. Annales de la Recherche Forestière, 29, 40-49.

Panouse, J.B. (1957) Les mammifères du Maroc. Travaux de l'Institut Scientifique Chérifien, Série Zoologique, 5, 1-206.

Schwarz, C.J. \& Seber, G.A. (1999) Estimating animal abundance: Review III. Statistical Science, 14, 427-456.

Seber, G.A.F. (1986) A review of estimating animal abundance. Biometrics, 42, 267-292.

Seddon, P.J., Ismail, K., Shobrak, M., Ostrowski, S. \& Magin, C. (2003) A comparison of derived population estimate, markresighting and distance sampling methods to determine the population size of a desert ungulate, the Arabian oryx. Oryx, 37, 286-294.

Slaughter, L. (1971) Gestation period of the dorcas gazelle. Journal of Mammalogy, 52, 480-481.

Thomas, L., Buckland, S.T., Rexstad, E.A., Laake, J.L., Strindierg, S., Hedley, S.L. et al. (2010) Distance software: design and analysis of distance sampling surveys for estimating population size. Journal of Applied Ecology, 47, 5-14.
Thomas, L., Laake, J.L., Strindberg, S., Marques, F.F.C., Buckland, S.T., Borchers, D.L. et al. (2005) Distance 5.o. Research Unit for Wildlife Population Assessment, University of St. Andrews, UK.

Whittaker, D.G., Van Dyke, W.A. \& Love, S.L. (2003) Evaluation of aerial line transect for estimating pronghorn antelope abundance in low-density populations. Wildlife Society Bulletin, 31, 443-453.

Yom-Tov, Y., Mendelssohn, H. \& Groves, C. (1995) Gazella dorcas. Mammalian species, 491, 1-6.

\section{Biographical sketches}

Moulay Abdeljalil Ait Baamrane is studying the morphometrics, feeding ecology, parasitology, demographics and conservation biology of the Moroccan dorcas gazelle. MOH A M MED ZNARI has been working for more than 20 years on vertebrate ecology, ecophysiology and conservation biology, particularly of reptiles, birds and mammals. $\mathrm{He}$ is also the curator of vertebrates at the Natural History Museum of Marrakech, Cadi Ayyad University. Chris Loggers carries out research on the ecology and conservation of ungulates. SAID EL MERCHT is a forest and wildlife manager working particularly on ungulates and protected areas. Mohamed Naimi is studying freshwater turtles; he has previously worked on the ecology of marine fish and also participates in projects on the dorcas gazelle and Barbary macaque. 